\title{
Estimation of Idle Emissions from the On-Road Vehicles in Dhaka
}

\author{
M. M. Rana ${ }^{1 *}$, M. H. Khan ${ }^{1,3}$, M. A. K. Azad', S. Rahman', S. A. Kabir ${ }^{2}$ \\ ${ }^{1}$ Clean Air and Sustainable Environment Project, Department of Environment, E-16, Agargaon, \\ Dhaka - 1207 \\ ${ }^{2}$ Department of Environment, E-16, Agargaon, Dhaka - 1207 \\ ${ }^{3}$ Ministry of Environment, Forest and Climate Change, Bangladesh Secretariat, Dhaka - 1000
}

Received 30 May 2019, accepted in final revised form 22 September 2019

\begin{abstract}
Vehicle emission is a major source of air pollution in Dhaka. Old fleet, lack of maintenance, improper traffic and parking management, overloading, fuel adulteration etc. are responsible for high emissions from the vehicle sector. In this study, vehicle emissions have been measured on-road in Dhaka using an Automotive Gas Analyzer and Smoke Opacity Meter to determine the existing vehicle emission scenario in the city. Concentrations of carbon monoxide (CO) and hydrocarbons (HC) in the emissions from $\mathrm{CNG}$ /gasoline vehicles, and opacity of the emissions from diesel vehicles were measured. The results were compared with the corresponding national limit values. It was found that all types of CNG vehicles performed very well with more than $80 \%$ satisfying the corresponding limit values. Private cars ranked at the top in performance among the CNG/gasoline vehicles. Diesel vehicles were found as the worst polluters in the vehicle sector; emissions from about $75 \%$ of the diesel vehicles had opacity more than $65 \mathrm{HSU}$, the national limit value for emissions from diesel vehicles. Motor cycles were also highly polluting; $60 \%$ of the motor cycles emitted $\mathrm{CO}$ and $\mathrm{HC}$ concentrations higher than the respective national emission limit values.
\end{abstract}

Keywords: Air Pollution; Vehicle; Emission; Opacity; Idle Emission Test.

(C) 2020 JSR Publications. ISSN: 2070-0237 (Print); 2070-0245 (Online). All rights reserved. doi: http://dx.doi.org/10.3329/jsr.v12i1.41501 J. Sci. Res. 12 (1), 15-27 (2020)

\section{Introduction}

Air pollution has become a serious concern for public health in many urban areas of Bangladesh [1,2]. Annual averages of fine particulate matter $\left(\mathrm{PM}_{2.5}\right)$ concentrations in the air of Dhaka during 2013 to 2014 were found about six times greater than the standards for $\mathrm{PM}_{2.5}$ in Bangladesh [3]. Higher pollution scenarios usually happen in dry season (November - April), which poses great threat to the human health in the country. About 92000 early deaths from the exposure to air pollution throughout the country of

*orresponding author: ranamasud2002@yahoo.com 
Bangladesh in 2010 were calculated [4], out of which about 13100 deaths were estimated in Dhaka alone.

Vehicle emission is one of the major sources of air pollution in the city [5]. Irregular maintenance, inadequate enforcement, improper traffic and parking systems, overloading, etc. are responsible for high emissions from vehicles in the city. The growth of vehicles in Dhaka is also high. Statistics from the Bangladesh Road Transport Authority (BRTA) show that the number of vehicles in Dhaka has increased by about $67 \%$ in the last eight years [6]. However, in spite of this surge in vehicle numbers in the city overall contribution of this sector to air pollution has decreased for some control measures being taken and implemented by the Government of Bangladesh. The emission standards for new and in-use vehicles were set in 2005. Two-stroke three-wheeled baby taxis which were one of the main contributors to the air pollution of Dhaka were driven out from the city from the $1^{\text {st }}$ January 2003. It was estimated that $\mathrm{PM}_{2.5}$ concentration in Dhaka was decreased by about $41 \%$ as a result of this removal of those two-stroke baby-taxis [7]. The introduction of cleaner fuel compressed natural gas $(\mathrm{CNG})$ to vehicle sector in early $90 \mathrm{~s}$ and its massive usage from early 20 s also helped reduce particulate emissions from the vehicle sector in Dhaka. The reforms in the vehicle sector have accordingly altered the source contributions to $\mathrm{PM}_{2.5}$ concentrations in the city. Latest apportionment study conducted with the data from 2010-2012 under the Clean Air and Sustainable Environment (CASE) project of the Department of Environment (DoE) attributed about $58 \%$ of fine particulate matter concentration in Dhaka to the brick manufacturing industries, $10.4 \%$ to vehicles and $15.3 \%$ to dust sources [8], whereas the previous apportionment study found 22.0, 36.0 and $24.5 \%$ contributions from these sources respectively [9].

CASE project conducted vehicle emission testing with an aim to assess the existing emission scenario of the in-use vehicles in Dhaka. Idle carbon monoxide (CO) and hydrocarbons (HC) from the gasoline/CNG vehicles and free acceleration smoke opacity of diesel vehicles were measured. Overall 1317 vehicles were tested at 08 hotspots in the city, out of which 815 were CNG/gasoline vehicles and 502 were diesel vehicles. This work is first of its kind in Bangladesh and bears high importance in understanding and managing the vehicle emissions in the country.

\section{Experimental}

\subsection{Emission testing sites}

Vehicle emission testing was carried out in 08 different hot-spots of Dhaka City from 2011 to 2015; the spots were chosen in different routes of the city so that vehicles plying to all directions could be tested. The spots were Abdullahpur (Uttara), Joar Shahara (Airport Road), Police Staff College (Mirpur - 14), Taltala (Agargaon), Darussalam (Mirpur), Sobhanbagh (Dhanmondi), Manik Mia Avenue (Tejgaon), and Notun Bazar (Badda) (Fig. 1). 


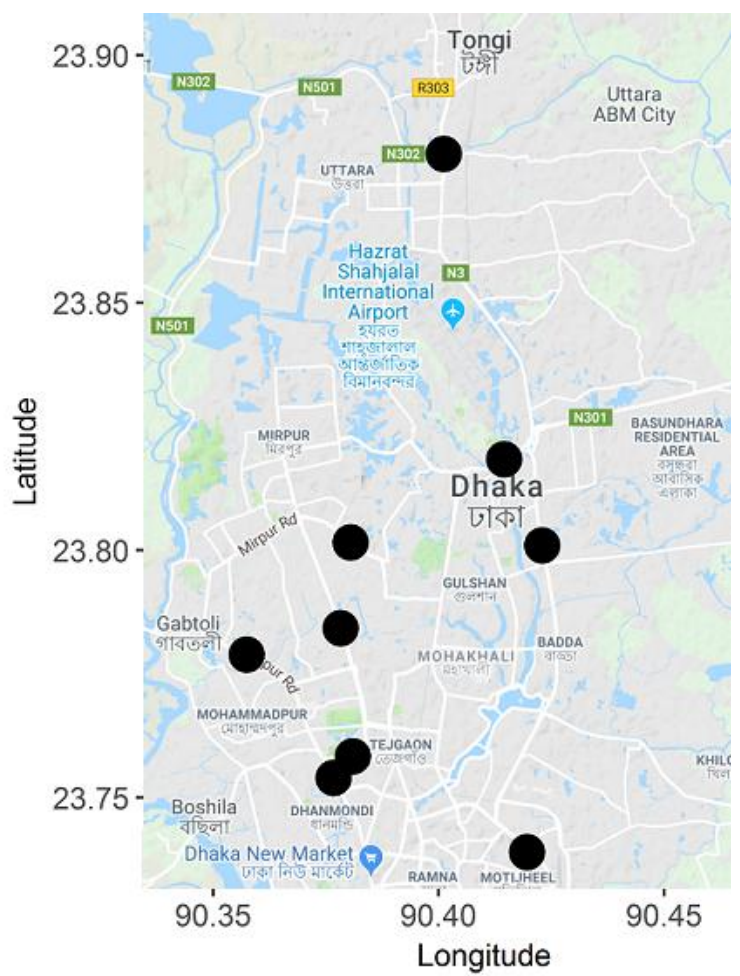

Fig. 1. Vehicle emission testing sites in Dhaka city.

\subsection{Instrument and method of testing}

A HORIBA made Automotive Gas Analyzer (model-MEXA 554 JA) was used to measure idle $\mathrm{HC}$ and $\mathrm{CO}$ emissions from the gasoline/CNG vehicles. The instrument analyzes gases (CO, HC) based on the Non Dispersive Infra Red (NDIR) method. During the testing, $\mathrm{CO}_{2}$ was also measured to check dilution of the exhaust gases by air in the exhaust system or during sampling. The analyzers were calibrated using National Institute of Standards and Technology (NIST) traceable gases at least once every day before the measurement started. If felt necessary, the analyzers were re-calibrated on the spot during the progress of the emission measurements. Leak checks and HC hang-up tests were performed as per the manufacturer's instructions. Idle tests were carried out in all cases (test procedure is given in the appendices).

A WAGER 6500 full flow smoke opacity meter was used to estimate smoke opacity of the emission from diesel vehicles. Smoke opacity measurement under the free acceleration test by a full flow smoke opacity meter was performed according to the method SAE J1667. The diameter of the vehicle exhaust pipe or of the extension pipe, if used, was also recorded to convert the smoke density in terms of $\mathrm{m}^{-1}$ unit to \% opacity for a common optical path length of $430 \mathrm{~mm}$, as applicable for Hartridge Smoke Unit (HSU). 


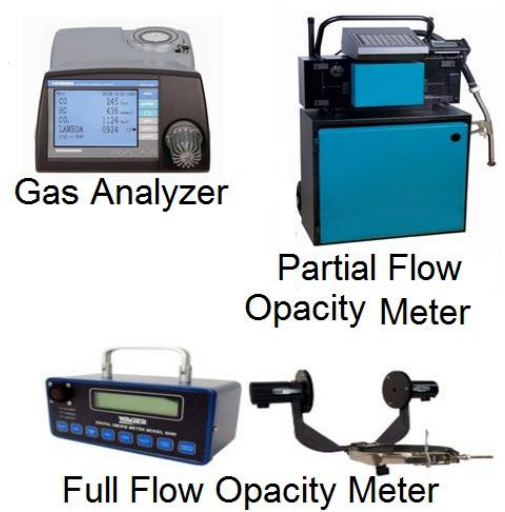

Fig. 2. Instrument for vehicle emission testing.

\subsection{Vehicle emission limit values}

The emissions standards of different types of vehicles were revised and notified in 2005 by the Government of Bangladesh (gazette SRO\# 220-Law/2005). Emission standards of different categories in-use vehicles are provided in Tables 1-2.

Table 1. Emission standards for petrol and CNG driven vehicles registered before September 1, 2004.

\begin{tabular}{|c|c|c|c|}
\hline Vehicle Type & Test & $\mathrm{CO}(\% \mathrm{v})$ & $\mathrm{HC}(\mathrm{ppm})$ \\
\hline 4-wheeled petrol & Idle Speed & 4.5 & 1,200 \\
\hline All CNG vehicles & Idle Speed & 3.0 & - \\
\hline $\begin{array}{l}\text { Petrol driven 2-Stroke engine } 2 \text { and } \\
3 \text {-wheelers }\end{array}$ & Idle Speed & 7.0 & 12,000 \\
\hline $\begin{array}{l}\text { Petrol driven 4-Stroke } 2 \text { and } 3 \text { - } \\
\text { wheelers }\end{array}$ & Idle Speed & 7.0 & 3,000 \\
\hline
\end{tabular}

Note: Idle Speed RPM to be specified by the manufacturer.

Table 2. Emission standards for vehicles registered after September 1, 2004.

\begin{tabular}{|c|c|c|c|c|c|}
\hline Vehicle Type & Test & $\begin{array}{l}\mathrm{CO}(\% \\
\mathrm{v})\end{array}$ & $\begin{array}{c}\mathrm{HC} \\
(\mathrm{ppm})\end{array}$ & $\begin{array}{c}\text { Lambda } \\
(\lambda)\end{array}$ & $\begin{array}{l}\text { Smoke } \\
\text { Opacity }\end{array}$ \\
\hline \multirow{2}{*}{$\begin{array}{l}\text { 4-wheeled petrol and } \\
\text { CNG vehicles }\end{array}$} & Idle Speed & 1.0 & 1200 & - & - \\
\hline & $\begin{array}{c}\text { No load, } \\
\text { 2500-3000 RPM }\end{array}$ & 0.5 & 300 & $1.0 \pm 0.03$ & - \\
\hline $\begin{array}{l}\text { Petrol driven 4-Stroke } 2 \\
\text { and 3-wheelers }\end{array}$ & Idle Speed & 4.5 & 1200 & - & - \\
\hline CNG driven 3-wheelers & Idle Speed & 3.0 & - & - & - \\
\hline $\begin{array}{l}\text { Naturally aspirated } \\
\text { diesel vehicles }\end{array}$ & Free acceleration & - & - & - & $\begin{array}{l}65 \mathrm{HSU}^{-1} \\
2.5 \mathrm{~m}^{-1}\end{array}$ \\
\hline $\begin{array}{l}\text { Turbo-charged diesel } \\
\text { vehicles }\end{array}$ & Free acceleration & - & - & - & $\begin{array}{l}72 \mathrm{HSU} \text { or } \\
3.0 \mathrm{~m}^{-1}\end{array}$ \\
\hline
\end{tabular}

Note: Idle speed RPM to be specified by the vehicle manufacturer. 


\subsection{Classification of vehicles}

Vehicles with great varieties in their fuel-use, capacity, size and weight, manufacturing years, etc. ply on the roads. Because of heavy traffic movement and absence of legal documents (in many cases) with the drivers, it was fairly impossible to collect all the information of the vehicles for a proper classification. With this drawback, the vehicles were primarily classified, for this study, by their fuel use, (1) CNG/gasoline vehicles and (2) Diesel vehicles. Table-3 shows detailed classification and name/type of the vehicles under each class.

Table 3. Classification of the vehicles tested.

\begin{tabular}{|c|c|c|}
\hline Category & Local names of vehicles & $\begin{array}{l}\text { Number of } \\
\text { vehicle tested }\end{array}$ \\
\hline \multicolumn{3}{|l|}{ CNG/Octane } \\
\hline Auto Ricksaw & Auto Ricksaw & 144 \\
\hline Bus & Bus, Minibus & 67 \\
\hline Car & $\begin{array}{l}\text { Private car, human hauler, jeep, laguna, } \\
\text { mircobus, taxi }\end{array}$ & 243 \\
\hline $\begin{array}{l}\text { Light Duty } \\
\text { Vehicle }\end{array}$ & $\begin{array}{l}\text { Pickup, minivan, mini truck, mini covered } \\
\text { van, delivery van, mini delivery van }\end{array}$ & 118 \\
\hline Motor Cycle & Motor Cycle & 243 \\
\hline \multicolumn{3}{|l|}{ Diesel } \\
\hline Bus & Bus, Minibus & 158 \\
\hline Truck & $\begin{array}{l}\text { Covered Van (heavy duty), Concrete } \\
\text { Mixtures, Lorries, Trucks }\end{array}$ & 141 \\
\hline $\begin{array}{l}\text { Light Duty } \\
\text { Vehicle }\end{array}$ & $\begin{array}{l}\text { Delivery van, human hauler, jeep, leguna, } \\
\text { mini truck, maxi, microbus, mini } \\
\text { covered/delivery van, pick up, rider }\end{array}$ & 203 \\
\hline
\end{tabular}

\subsection{Vehicle number and growth}

Steady economic growth and ongoing urbanization in recent years in the county have instigated vehicle numbers to grow fast in the urban areas. It is estimated that the number of vehicles registered in Dhaka alone up to June 2018 is 1.67 times high of the number in 2010. Table 4 shows the number of different types of vehicles registered in Dhaka up to June 2018 [9].

The statistics reveal that the Light Duty Vehicles (LDV) have increased greatly (183\%) within the period from 2010 to 2018; human hauler, jeep, leguna, mini truck, maxi, microbus, mini-van, pick up, rider, etc. are within the category of LDV. The increase in Auto Rickshaws, buses and cars were moderate, all of these categories have increased by about 50\%. Truck numbers have doubled in the last 8 years; a portion of new heavy duty trucks runs on CNG. 
Table 4. Number and increase of different category vehicles registered in Dhaka up to 2010 and up to 2018.

\begin{tabular}{lccc}
\hline Vehicle category & $\begin{array}{c}\text { Registered up } \\
\text { to } 2010\end{array}$ & $\begin{array}{c}\text { Registered up to } \\
\text { June 2018 }\end{array}$ & $\begin{array}{c}\% \\
\text { increase }\end{array}$ \\
\hline Auto Rickshaw & 7664 & 11467 & 50.0 \\
Bus & 26273 & 39375 & 50.0 \\
Car & 268829 & 399808 & 49.0 \\
LDV & 39989 & 112220 & 183.0 \\
Truck & 26922 & 56784 & 111.0 \\
Total & 369677 & 619654 & 67.6 \\
\hline
\end{tabular}

\subsection{Data correction}

For a 4-stroke petrol engine, sum of $\mathrm{CO} \%$ and $\mathrm{CO}_{2} \%$ should be 15 or higher and for $\mathrm{CNG}$ engine it should be 12 or higher. When the sum of these two gases for an individual test was less, exhaust gas dilution was suspected and the observed $\mathrm{CO}$ and $\mathrm{HC}$ concentrations were corrected. Similarly, for a 2 -stroke petrol engine $\mathrm{CO} \%+\mathrm{CO}_{2} \%$ should be 10 or higher and the concentration of $\mathrm{CO}$ and $\mathrm{HC}$ were corrected when the sum was less than 10. In all cases corrections were done as per the following equations (Eq.1 to 6),

(a) For 4-S Petrol Engine:

$$
\begin{aligned}
& \mathrm{CO}_{\text {corr }}=\mathrm{CO}_{\text {meas }}(\%) \mathrm{x} \frac{15}{[\mathrm{CO} \%+\mathrm{CO} 2 \%] \text { meas }} \% \\
& \mathrm{HC}_{\text {corr }}=\mathrm{HC}_{\text {meas }}(\mathrm{ppm}) \times \frac{15}{[\mathrm{CO} \%+\mathrm{CO} \%] \text { meas }} \mathrm{ppm}
\end{aligned}
$$

(b) For 2-S Petrol Engines:

$$
\begin{aligned}
& \mathrm{CO}_{\text {corr }}=\mathrm{CO}_{\text {meas }}(\%) \times \frac{10}{[\mathrm{CO} \%+\mathrm{CO} 2 \%] \text { meas }} \% \\
& \mathrm{HC}_{\text {corr }}=\mathrm{HC}_{\text {meas }}(\mathrm{ppm}) \times \frac{10}{[\mathrm{CO} \%+\mathrm{CO} \%] \text { meas }} \mathrm{ppm}
\end{aligned}
$$

(c) For 4-S CNG Engines:

$$
\begin{aligned}
& \mathrm{CO}_{\text {corr }}=\mathrm{CO}_{\text {meas }}(\%) \times \frac{12}{[\mathrm{CO} \%+\mathrm{CO} 2 \%] \text { meas }} \% \\
& \mathrm{HC}_{\text {corr }}=\mathrm{HC}_{\text {meas }}(\mathrm{ppm}) \times \frac{12}{[\mathrm{CO} \%+\mathrm{CO} 2 \%] \text { meas }} \mathrm{ppm}
\end{aligned}
$$

Where $\mathrm{CO}_{\text {corr }}$ and $\mathrm{HC}_{\text {corr }}$ are corrected concentration of $\mathrm{CO}$ and $\mathrm{HC}$ 


\section{Results and Discussion}

\subsection{Overview of vehicle performance}

The vehicle emission measurements were mainly Dhaka centric as $40 \%$ of the vehicles in the country are registered in Dhaka alone, and also for a great portion of populations in the city lives under a threat of increased level of air pollution to which vehicle sector is a big contributor. The emission testing results were compared with the corresponding limit values - the vehicles were tagged with "Passed" when the emission results satisfied the respective limit values and with "Failed" when the results were over the limit values. Table 5 gives an overview of the performance of different category vehicles. The result shows that the auto rickshaws and cars performed very well in respect to the standards set by the Government; $92.3 \%$ of the auto rickshaws and $87.8 \%$ of the cars could meet the national standards. However, $\mathrm{CNG}$ driven bus and light duty vehicles with success rates of 74.5 and $76.7 \%$ respectively should have done further better in consideration of using the cleaner fuel. The performances of motor cycles were found very pale; its performance rate was only $22.2 \%$.

On the other hand, diesel vehicles irrespective of the category performed very poorly. About $84 \%$ of the diesel buses and minibuses were found emitting smokes with opacity more than the limit value, while $69 \%$ trucks and $58.6 \%$ LDVs were unsuccessful in meeting the national limit values (Table 5).

Table 5. Overview of the performances of different category vehicles.

\begin{tabular}{lccccc}
\hline Category & $\begin{array}{c}\text { CNG/Octane Vehicles } \\
\text { Number of } \\
\text { vehicles tested }\end{array}$ & $\begin{array}{c}\% \text { of vehicles } \\
\text { passed }\end{array}$ & Category & $\begin{array}{c}\text { Diesel Vehicles } \\
\text { Number of } \\
\text { vehicles tested }\end{array}$ & $\begin{array}{c}\% \text { of vehicles } \\
\text { passed }\end{array}$ \\
\hline Auto & 144 & 92.3 & Bus & 158 & 16.0 \\
Rickshaw & 67 & 74.5 & LDV & 203 & 41.4 \\
Bus & 243 & 87.8 & Truck & 141 & 31.0 \\
Car & 118 & 76.7 & - & - & - \\
LDV & 243 & 22.2 & - & - & - \\
Motor & & & & & \\
Cycle & & & &
\end{tabular}

\subsection{Analyses of vehicle emission data}

\subsubsection{Idle CO emissions from CNG/Octane vehicles}

i. Among the CNG/octane vehicles auto rickshaws were the most effective in meeting the $\mathrm{CO}$ regulatory limits. About $83 \%$ and $86.0 \%$ of them exited emissions with CO concentrations less than 0.3 and $0.6 \%$ (v) respectively (Fig. 3), and about $95.0 \%$ of the auto rickshaws emitted $\mathrm{CO}$ concentrations less than $2.0 \%(\mathrm{v})$. The existing limit value of $\mathrm{CO}$ concentrations for this category vehicle is $3.0 \%(\mathrm{v})$. 
ii. About $70 \%$ of the cars emitted CO concentrations less than $0.3 \%$ (v); $77 \%$ of them passed the existing limit value of $1 \%$ (v) (Fig. 3).

iii. Buses performed little better than LDVs with respect to $\mathrm{CO}$ emissions - while $77 \%$ of the buses emitted CO concentration less than $1 \%$ (v), only $63 \%$ of LDVs did the same. $82 \%$ of the buses contrasted to only $70 \%$ of the LDVs exited CO concentrations below 2\%(v) (Fig. 3).

Table 6 shows a ranking of the $\mathrm{CNG}$ /octane vehicles in terms of their $\mathrm{CO}$ emission.

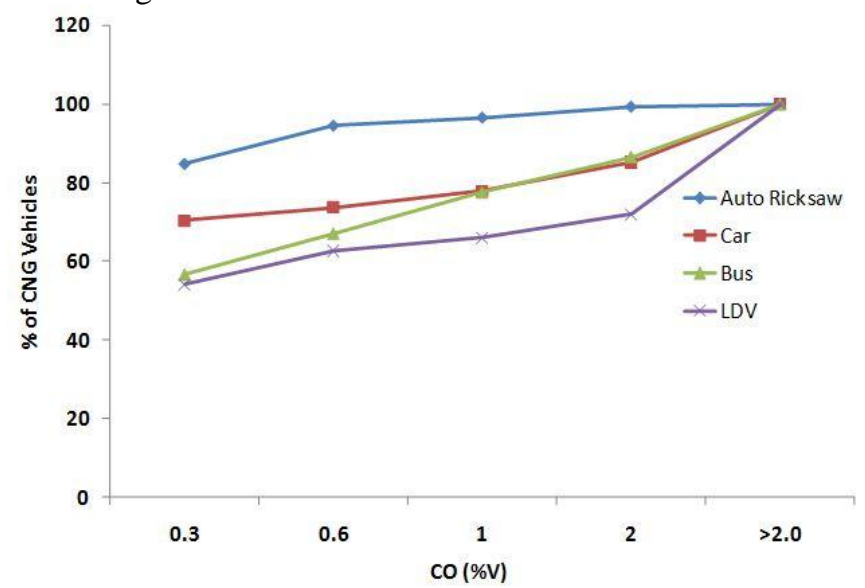

Fig. 3. Cumulative distributions of CNG vehicles for $\mathrm{CO}$ emissions.

Table 6. Ranking of CNG/Octane driven vehicles in respect to $\mathrm{CO}$ emissions.

\begin{tabular}{lcccc}
\hline Vehicle Category & \multicolumn{2}{c}{$\%$ of vehicle with CO emission (\%v) } & Rank \\
& $\leq 0.6$ & $\leq 1.0$ & $\leq 2.0$ & \\
\hline Auto rickshaw & 94.5 & 96.5 & 99.3 & $1^{\text {st }}$ \\
Car & 73.7 & 77.8 & 85.2 & $2^{\text {nd }}$ \\
Bus & 67.2 & 77.6 & 86.5 & $3^{\text {rd }}$ \\
LDV & 62.7 & 66.1 & 72.0 & $4^{\text {th }}$ \\
\hline
\end{tabular}

\subsubsection{Idle HC emissions from CNG/octane vehicles}

i. There is no national limit value for $\mathrm{HC}$ emissions from the on-road CNG three wheeled auto rickshaws; nevertheless, $\mathrm{HC}$ concentrations from this type of vehicles were recorded and analyzed to assess their performances. Fig. 4 shows the HC emitting potentials of different category $\mathrm{CNG}$ vehicles. It is found that $50.6 \%$ of auto rickshaws exited HC concentration $\leq 500 \mathrm{ppm}$ and $72 \%$ of these vehicles emitted $\mathrm{HC}$ at $\leq 1500 \mathrm{ppm}$. The result (Fig. 4) shows the CNG auto rickshaws were not so promising in $\mathrm{HC}$ emissions although those were very miser in $\mathrm{CO}$ emissions (Fig. 3).

ii. About $43.2 \%$ of buses exited HC concentrations at $\leq 500 \mathrm{ppm}$ and $87.0 \%$ of them emitted $\mathrm{HC}$ at $\leq 1500 \mathrm{ppm}$. All of the CNG driven buses emitted HC within $3000 \mathrm{ppm}$ (Fig. 4). 
iii. Cars and LDVs showed comparatively good results in $\mathrm{HC}$ emissions. About $74.3 \%$ of cars and $70.5 \%$ of LDVs emitted HC concentrations less than 500 ppm, and about $97.5 \%$ of these vehicles emitted $\mathrm{HC}$ at $\leq 1500 \mathrm{ppm}$.

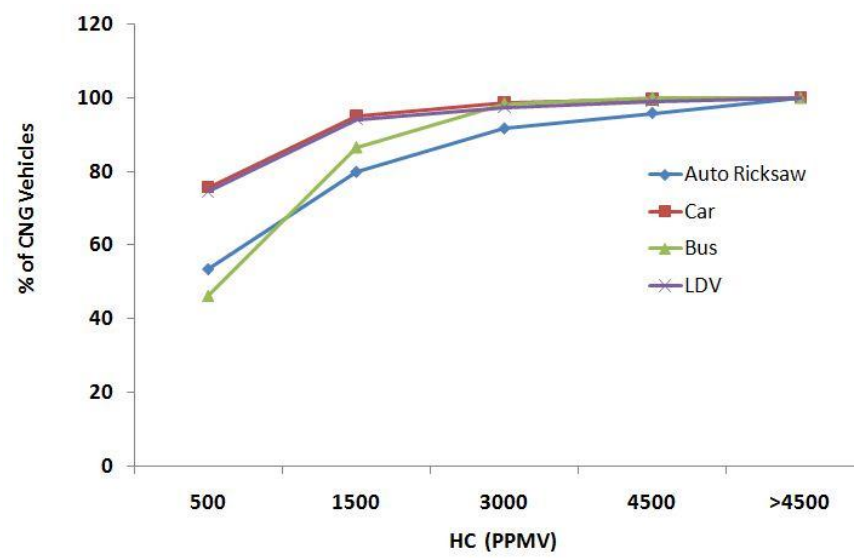

Fig. 4. Cumulative distributions of $\mathrm{CNG}$ vehicles for $\mathrm{HC}$ emissions.

Table 7. Ranking of CNG/Octane vehicles in respect to $\mathrm{HC}$ emissions.

\begin{tabular}{lccccc}
\hline Vehicle Category & \multicolumn{5}{c}{$\begin{array}{c}\text { \% of vehicle with HC emission } \\
(\mathrm{ppm})\end{array}$} \\
& \multicolumn{5}{c}{ Rank } \\
\hline Auto rickshaw & 53.5 & $\leq 1200$ & $\leq 3000$ & $\leq 4500$ \\
Car & 75.7 & 90.5 & 91.7 & 95.8 & $4^{\text {th }}$ \\
Bus & 46.3 & 80.6 & 98.5 & 99.6 & $1^{\text {st }}$ \\
LDV & 74.6 & 88.6 & 97.5 & 99.2 & $2^{\text {nd }}$ \\
\hline
\end{tabular}

\subsubsection{Idle $\mathrm{CO}$ and $\mathrm{HC}$ emissions from motor cycles}

i. Motorcycles were found as the worst polluters in the CNG/octane vehicle category. Fig. 5a shows that only $40 \%$ of the motorcycles exited emissions with $\mathrm{CO}$ concentrations $\leq$ $4.5 \%$ (v), the existing limit value for motor cycle emission. About $36.5 \%$ of these vehicles emitted $\mathrm{CO}$ concentrations greater than $7.0 \%(\mathrm{v})$, which may be considered very high emission.

ii. Motor cycles were also found high $\mathrm{HC}$ emitters among the CNG/octane category. It was found that only $37 \%$ of the motorcycles emitted $\mathrm{HC}$ at $\leq 1500 \mathrm{ppm}$, and about $58.8 \%$ emitted $\mathrm{HC}$ at $\leq 3000 \mathrm{ppm}$ (fig. 5b). The figure also shows that about $24 \%$ of the motorcycles emitted HC greater than 5000 ppm that may be considered very high. 


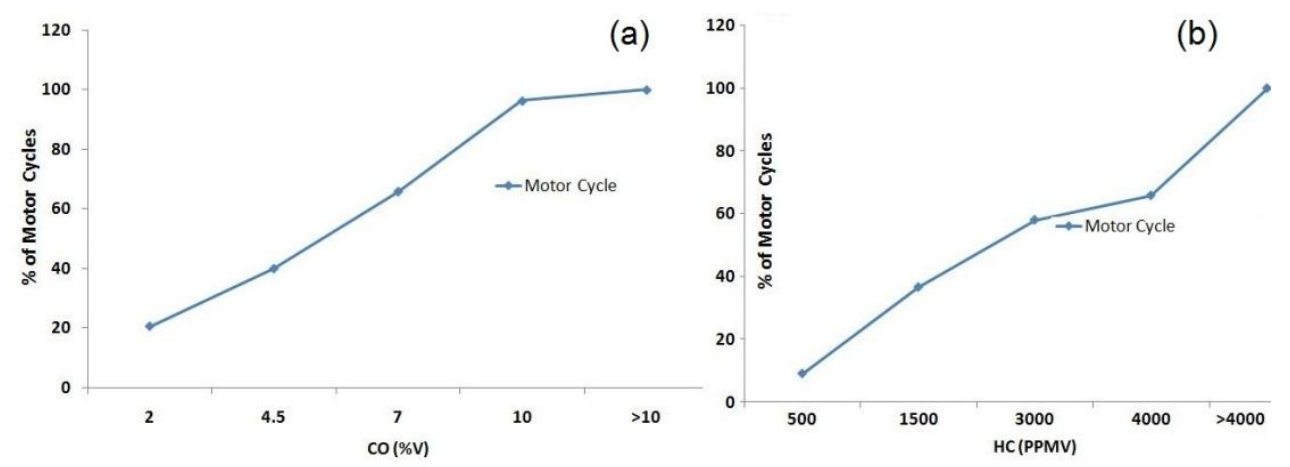

Fig. 5. Cumulative distributions of motor cycles for (a) $\mathrm{CO}$ and (b) $\mathrm{HC}$ emissions.

\subsubsection{Comparative positions of CNG/Octane vehicles with respect to Idle CO at $1 \% \mathrm{v}$ and idle HC at 1200 ppm}

Irrespective of the manufacturing year, the vehicles were sorted according to their performances in simultaneously emitting $\mathrm{CO}$ within $1 \%(\mathrm{v})$ and $\mathrm{HC}$ within $1200 \mathrm{ppm}$ concentrations which are the existing limit values for the CNG/gasoline vehicles registered after 01 September 2004. It is found that the cars ranked at the top with $71.6 \%$ meeting those limit values simultaneously, while the auto rickshaws stood at the second place with $68 \%$ compliance. LDVs and Buses performed very closely with 59.1 and 59.6 $\%$ compliance respectively.

\subsubsection{Analysis of smoke emissions from diesel vehicles}

i. Buses were found to be the highest polluters among the diesel vehicles. This category includes heavy duty buses which are mainly district bound vehicles, and mini buses which ply within the city. Most of the minibuses in Dhaka city are converted to the CNG system, but a fraction of them are still running on diesel. It is seen from the data analysis that only $18 \%$ of the buses could meet the national limit value of 65 HSU opacity. More than $70 \%$ buses emitted smoke with opacity greater than 85 HSU. Fig. 6 shows cumulative distribution of different category diesel vehicles with respect to their smoke opacity.

ii. Trucks followed nearly the same status as buses did. Only $24.6 \%$ of the trucks could satisfy existing limit value of $65 \mathrm{HSU}$, and about $65 \%$ of trucks emitted smoke with opacity greater than 85 HSU (Fig. 6). As heavy duty trucks and buses are allowed entering the Dhaka City after $10.00 \mathrm{pm}$, large number of those vehicles waiting outskirts of the city from the evening rush in to the city at $10: 00 \mathrm{pm}$, stimulating ambient air pollution in the city.

iii. Among the diesel vehicles LDVs performed little better compared to buses and trucks (Fig. 6). $40.9 \%$ of LDVs could satisfy limit value of $65 \mathrm{HSU}$ and about $50 \%$ of them had smoke opacity greater than 85 HSU 


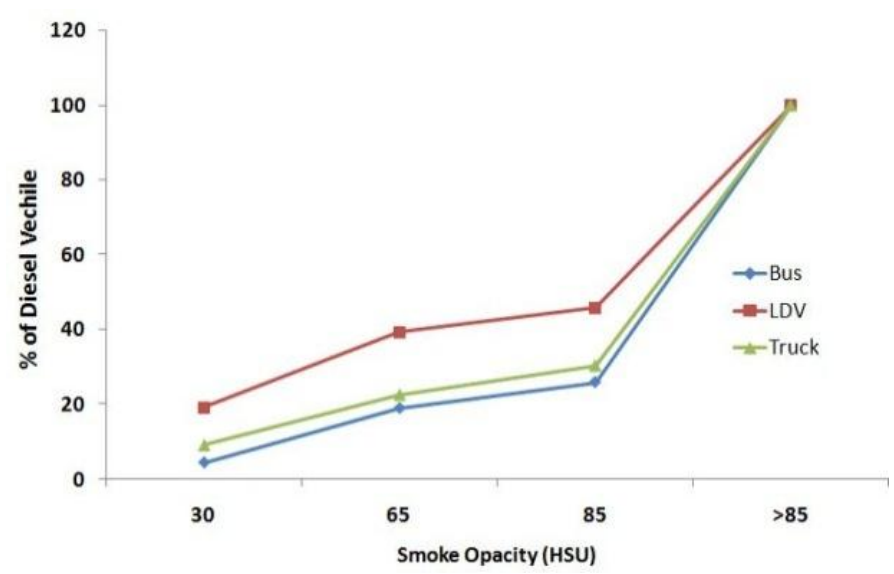

Fig. 6. Cumulative distributions of diesel vehicles for smoke opacity.

\section{Conclusion}

On-road vehicle emission testing was carried out on $815 \mathrm{CNG} /$ gasoline and 502 diesel vehicles in 08 hot-spots of Dhaka from 2012 to 2015. Idle measurement of carbon monoxide (CO) and hydrocarbons ( $\mathrm{HC}$ ) in the emissions from CNG/gasoline vehicles, and opacity of the emissions from diesel vehicles were conducted. The results showed that all types of CNG vehicles performed very well with more than $80 \%$ satisfying the corresponding limit values. Private cars ranked at the top in performance among the $\mathrm{CNG}$ /gasoline vehicles. Contrasted to the performance of the CNG vehicles all types of diesel vehicles were found highly polluting; emissions from about $75 \%$ of the diesel vehicles had opacity more than $65 \mathrm{HSU}$, the national emission limit value for the diesel vehicles. Motor cycles were also highly polluting; $60 \%$ of the motor cycles were found unsuccessful in satisfying the corresponding limit value. Further analyses of the emission monitoring data resulted the following findings,

(a) About $75 \%$ of the $\mathrm{CNG}$ vehicles emitted $\mathrm{CO} \leq 1 \%$ (v) concentration and about $88 \%$ of the vehicles emitted $\mathrm{CO} \leq 3 \%(\mathrm{v})$ concentrations. HC emissions from these vehicles were also promising - about $85 \%$ of CNG vehicles emitted $\mathrm{HC}$ $\leq 1200 \mathrm{ppm}$ concentrations.

(b) Only $40 \%$ of the motorcycles could meet the $\mathrm{CO}$ emission standard of $4.5 \%(\mathrm{v})$; about $35 \%$ of the motorcycles emitted CO concentrations more than $7 \%(\mathrm{v})$. The scenario for $\mathrm{HC}$ emission from motorcycle was about the same; only $30 \%$ of motorcycles satisfied the limit value of $1200 \mathrm{ppm}$.

(c) Only $23 \%$ of diesel buses and trucks could meet the limit value of $65 \mathrm{HSU}$ opacity and about $67 \%$ of them had emissions with opacity $>85$ HSU. 


\section{Appendices}

\section{Appendix A: Guidelines for measurement of $\mathrm{CO}$ and $\mathrm{HC}$ emissions from spark ignition engine vehicles (Idle test)}

The idle $\mathrm{CO}$ and $\mathrm{HC}$ emission inspection tests were completed in the following phases:
i. Test equipment set up
ii. Vehicle Preparation
iii. Execution of idle test

\section{(i) Test preparation and equipment setup}

(a) A NDIR gas analyzer for measurement of concentration of $\mathrm{CO}$ and $\mathrm{HC}$ as hexane shall be used. In addition, $\mathrm{CO}_{2}$ will also be measured for correction of measured $\mathrm{CO}$ and $\mathrm{HC}$ for any leakage or air into the exhaust system. The exhaust gas analyzer shall have capability to measure Lambda for testing of vehicles equipped with 3-way catalytic converters.

(b) Follow instructions provided by the manufacturers of analyzers for operation of the gas analyzers.

(c) Analyzers should be calibrated daily at the beginning of work but no more than 4 hours before use. Each time the instrument is moved or transferred to new location, perform a span and zero calibration using calibration gas. Follow the instructions in the user manual of the analyzers.

(d) Ensure any filters in the sampling line are clean.

(e) Ensure that there are no leaks in the sampling line. Carry out leak test on analyzer if there is provision.

(f) Ensure that the sampling handling line and probe are free from contaminants by carrying out periodic hang up test. HC reading should drop to $20 \mathrm{ppm}$ or less within 5 minutes when the probe is removed from the exhaust. If it takes more than 5 minutes for $\mathrm{HC}$ reading to drop to $20 \mathrm{ppm}$ or less, then replace the probe with a new one.

(g) Purge the system after measurements on each vehicle as per the manufacturer's instructions.

(h) If the analyzer has provision to key in vehicle data such as registration no., make, date or test, etc., then feed in the information.

\section{(ii) Vehicle preparations}

Prior to conducting the test, following items must be completed,

(a) Vehicles should have been warmed up by operation for $10 \mathrm{~km}$ or 15 minutes before emission measurement.

(b) If the vehicle is equipped with a manual transmission, the transmission must be placed in neutral gear and clutch must be released. If the vehicle is equipped with an automatic transmission, the transmission must be placed in the park position, if available, or otherwise in the neutral position.

(c)Vehicle wheels or the vehicle must be restrained to prevent from moving during testing.

(d) Vehicle accessories such as air conditioning, fan, radio, etc., should be turned off.

(e) The vehicle should be inspected for exhaust leaks. Severe leaks in the system may cause air to enter into the exhaust stream, which may give erroneously low test results.

(f) Ensure that manual choke control has been returned to rest position. 
(g) Where the vehicle is equipped with an exhaust system having multiple outlets, either these shall be joined to a common pipe or the $\mathrm{CO}, \mathrm{CO}_{2}$ and $\mathrm{HC}$ content from each of them shall be measured and the result of the test would be reached by taking arithmetical average of these concentrations for each pollutants.

\section{(iii) Execution of idle test}

(a) Ensure vehicle is prepared as discussed above.

(b) If an engine RPM tachometer is available, note engine idle speed.

(c) Insert analyzer probe into vehicle tail pipe at least $300 \mathrm{~mm}$. Use an exhaust pipe extension if necessary.

(d) Allow the exhaust emissions measurement reading to stabilize for approximately 1 minute.

(e) Record or print out results. Note any abnormalities.

(f) For vehicle equipped with a catalytic converter and where an engine RPM tachometer is available, an additional test is to be carried out with the engine idle speed held constant at approximately 2000 RPM.

\section{References}

1. A. Salam, T. Hossain, M. N. A. Siddique, and A. M. S Alam, Air Qual. Atmos. Health 1, 101 (2008). https://doi.org/10.1007/s11869-008-0017-8

2. B. A. Begum and P.K. Hopke, Aerosol Air Qual. Res. 19, 118 (2019). https://doi.org/10.4209/aaqr.2017.12.0604

3. M. M. Rana, N. Sulaiman, B. Sivertsen, M. F. Khan, and S. Nasrin, Environ. Sci. Pollut. Res. 23, 17393 (2016). https://doi.org/10.1007/s11356-016-6950-4

4. J. Leliveld, J. S. Evans, M. Fnais, D. Giannadaki, and A. Pozzer, Nature 525, 367 (2015). https://doi.org/10.1038/nature15371

5. A. K. Azad and T. Kitada, Atmos. Environ. 32, 1991 (1998). https://doi.org/10.1016/S13522310(97)00508-6

6. Bangladesh Road Transport Authority (BRTA), Date of access 22/09/2019. www.brta.gov.bd

7. B. A. Begum, S. K. Biswas, and P.K. Hopke, J. Air Waste Manage. 56, 85 (2006). https://doi.org/10.1080/10473289.2006.10464430

8. Clean Air and Sustainable Environment (CASE) Project, In: S-13-Source Apportionment-All Elements Report, Date of access 22/09/2019 http://case.doe.gov.bd

9. B. A. Begum, P. K. Hopke, and A. Markwitz, Atmos. Pollut. Res. 4, 75 (2013). https://doi.org/10.5094/APR.2013.008 